\title{
‘Euro-lab’ scientists seek fairer deal on pay
}

Munich. Labour relations in Europe's international laboratories are becoming strained as their scientists, who are not allowed to join trade unions and have no collective bargaining rights, are taking their complaints about the way salary claims are being handled to the International Labour Organization (ILO) in Geneva.

Most scientists working in organizations such as the European Southern Observatory (ESO), the European Molecular Biology Laboratory (EMBL) and the European Laboratory for Particle Physics (CERN) are paid considerably more than those working for national research bodies typical researchers may receive a tax-free salary of almost $\$ 70,000$ a year - to compensate for the disruption of living abroad.

In recent years, one way in which governments have tried to keep down the costs of such organizations has been by restricting salary increases. But their researchers are now claiming that such moves conflict with accepted guidelines covering staff working for international bodies.

Later this month, for example, the council of ESO, whose headquarters are in Garching, near Munich, will decide whether to implement the recent ruling of an ILO administrative tribunal that it should raise salaries which, according the ILO, have been kept unfairly low since 1992. According to its statutes, ESO has agreed to refer any salary dispute that cannot be resolved internally to the ILO.

Staff at the EMBL, who believe that they are in an identical position, are also threatening to take the Heidelberg organization to the same administrative tribunal if they do not receive a compromise pay adjustment in the next weeks.

Both claims come at a difficult financial time for the two bodies, which are trying to expand their research efforts despite

\section{CERN researchers may appeal again}

\begin{abstract}
Munich. Scientists at the European Laboratory for Particle Physics (CERN) in Geneva have taken salary claims to the ILO every year since 1992, but so far without success; CERN never agreed to follow the salary recommendations of the Coordinated Organizations (see above), preferring to base its indexation on the inflation rate in Geneva.
\end{abstract}

When wages were kept below this rate at the request of CERN council in 1992 , the staff association appealed to the ILO. But the organization ruled that, technically, CERN had no legal obligation to meet the criteria on pay increases it set itself 15 years ago. "In that respect they differ from the methods that other constrained budgets. Some argue that EMBL in particular could face major financial difficulties if the staff claim is met in full. But many scientists complain that the absence of an agreed system for adjusting salaries has left them vulnerable to budgetary constraints.

The problem is relatively new. In the early 1980s, both ESO and EMBL agreed to base their annual salary increments on the index recommended by the Coordinated Organizations (CO). This is a committee within the Organization for Economic Co-operation and Development in Paris which makes recommendations on pay for bodies such as the North Atlantic Treaty Organisation and the European Space Agency.

In 1993, however, the ESO council decided to implement only two-thirds of the $\mathrm{CO}$ recommendation, and to make this retroactive to 1992 . It pointed out that it is not a member of the $\mathrm{CO}$ itself, and that the clause in its constitution declaring its intention to follow the $\mathrm{CO}$ recommendations includes the rider that the council will make the final decision on pay matters.

But this defence has been rejected by the ILO administrative tribunal. In a ruling in February on two complaints from ESO staff members, the tribunal argued that ESO had set a precedent on pay procedures over the previous ten years on which staff had come to rely. It concluded that ESO should raise salaries to the level they should have been if the CO recommendations had been followed, and compensate fully for any consequent loss of earnings.

ESO refuses to says how much this will cost. But a spokesman, Richard West, says the council has little alternative to paying up, as its member states have already

organizations follow", concluded an ILO tribunal.

But in the light of the recent ruling against ESO that the precedents which were followed in previous years should be adhered to, the staff association is appealing once again to the ILO, claiming that their expectation of pay increases based on the Geneva inflation rate has been breached.

CERN pay has been frozen for the next few years, as the laboratory seeks to hold down costs in order to pay for the Large Hadron Collider. But the administration has recently launched an internal review of its employment conditions.

A. A. agreed to accept ILO's rulings.

The ESO council will now decide how to avoid similar problems in the future. "Any agreement which is fair, transparent and stable is okay with us," says a representative of the staff association, claiming that "money is less important than principles, particularly in situations [like ours] where there is no right to collective bargaining or unionization". He acknowledges that staff are well-paid, but says they want to ensure that ESO sticks to its rules of procedure.

EMBL also abandoned its automatic adherence to $\mathrm{CO}$ recommendations a few years ago, and its staff association is now discussing the implications of the ESO ruling with a working group set up by the council of the laboratory.

Full implementation of the ILO's recommended indexation would add DM2 million (US\$1.4 million) to this year's salary bill, says Barton Dodd, head of EMBL's administration. Back pay to mid-1993, when the disparities between recommended and actual pay increases began, he says, would cost EMBL a further DM2.5 million.

But Dodd still believes that salaries must remain competitive with those offered by national laboratories. "We ask people to disrupt their lives by coming here for relatively short periods - no more than nine years - and we have to pay a premium to get them here and keep them here", he says, arguing that if rises remain lower than inflation, EMBL salaries will lose their competitive edge.

Both the EMBL administration and the staff union hope to reach a compromise on pay. But obtaining the necessary approval of EMBL's member states may not be so easy, as they are unlikely to accept a settlement based on the ILO ruling on ESO. The main players - Germany, France and the United Kingdom - are hoping that the ILO would establish a new precedent if EMBL staff brought a similar case.

But whatever the outcome, says a spokesman for the German delegation to EMBL, member states are unlikely to pay out until required to do so, as the money involved - around two per cent of the annual budget - could undermine its ambitious research plans. EMBL council is expected to make a decision at its meeting at the end of this month.

Jean-Christoph Olivo, of EMBL's staff association, says that scientists are aware that the increases they are seeking could cause financial difficulties for the laboratory. But he says that they feel that they are being exploited, as EMBL has reneged on its agreement to follow $\mathrm{CO}$ indexation, and that if a compromise cannot be achieved, they feel they have no alternative but to refer their complaints to the ILO.

Alison Abbott 